\title{
PENGARUH MODEL PEMBELAJARAN TRI KAYA PARISUDHA TERHADAP PRESTASI BELAJAR MAHASISWA SEMESTER V PRODI PENDIDIKAN AGAMA HINDU STKIP AGAMA HINDU SINGARAJA TAHUN AKADEMIK 2016/2017
}

Oleh

I Nengah Dwi Endra Suanthara

\begin{abstract}
This study aims want to know description students' achievement and the effect of Tri Kaya Parisudha. Learning Model towards Students' achievement at $\mathrm{V}^{\text {st }}$ grade of Prodi Pendidikan Agama Hindu (PAH) STKIP Agama Hindu Singaraja.The Study was designed with experimental research exactly post test only control group design. Population of this study were all students at $\mathrm{V}^{\text {st }}$ grade that were 54 students that consist of 28 students class B and 26 students class A. The sampling technique used population study that were all of students at the class A and class B as a research subject. Determined experiment and control class in this reseach was used random sampling technique namely lottery technique. Based on the technique found that: class B to be experiment class and class A as control. Data collecting method were used: test, interview, document registration and observation. And then data analysis were descriptive and inferensial statistic namely t-test. Based on the analysis found that: mean score of experiment class = 84,36 more than the control class mean score $=72,44$. The result of hypothesis test in case used $5 \%(0,05)$ significance and $d f=52$, coefficient of $\mathrm{t}$-table $\left(\mathrm{t}_{\mathrm{t}}\right)=1,67$, and then observation coefficient $=1,78$. So, based on the analysis above can be concluded that there was the effect of Tri Kaya Parisudha towards students'achievement of MPP at the $\mathrm{V}^{\text {st }}$ grade students of Prodi Pendidikan STKIP Agama Hindu Singaraja. The result study can be done by lectures or teachers as a reference in teaching and learning process to improve education quality.
\end{abstract}

Key words: Tri Kaya Parisudha Leaning Model, Students' achievement.

\section{PENDAHULUAN}

Pembelajaran yang bermakna dapat membawa mahasiswa pada pengalaman belajar yang mengesankan. Pengalaman yang diperoleh mahasiswa dapat semakin berkesan apabila proses pembelajaran yang diperolehnya merupakan hasil dari pemahaman dan penemuannya sendiri. Dalam konteks ini mahasiswa mengalami dan melakukannya sendiri. Proses pembelajaran yang berlangsung hendaknya dapat melibatkan mahasiswa sepenuhnya untuk merumuskan sendiri suatu konsep. Keterlibatan dosen/guru hanya sebagai fasilitator dan moderator dalam proses pembelajaran tersebut. Merunut Kurikulum Berbasis Kompetensi yang 
disempurnakan bahwa setiap individu mempunyai potensi yang harus dikembangkan, maka proses pembelajaran yang cocok adalah yang menggali potensi anak untuk selalu kreatif dan berkembang. Namun kenyataan di lapangan belum menunjukkan ke arah pembelajaran yang bermakna. Apalagi di era global ini, perkembangan ilmu pengetahuan dan teknologi menjadi kunci keberhasilan seseorang baik sebagai mahasiswa atau dosen/guru. Para dosen/guru belum siap dengan kondisi yang sedemikian plural dan serba moderen atau berbasis imformasi teknologi (IT). Perkembangan teknologi yang demikian pesat mengakibatkan para dosen/guru menjadi kebingungan. Mereka belum paham sepenuhnya bagaimana mengelola pembelajaran yang tepat. Hal ini disebabkan perkembangan ilmu pengetahuan dan teknologi terlalu cepat dan lebih cepat dari perkembangan pengetahuan para dosen/guru. Perkembangan IPTEK tersebut berdampak luas pada pembelajaran seperti: penyusunan silabus dan rencana pembelajaran, assessment dan evaluasi, penggunaan metode, media, pendekatan yang berbasis IT dan lainlain. Kekurang mampuan dosen/guru dalam mengelola pembelajaran yang berbasis IT mengakibatkan proses pembelajaran dosen/guru bersifat konvensional yang tentu tidak menarik bagi mahasiswa. Faktor ini dapat berkontribusi kurang baik terhadap mutu pendidikan. Hasil kuisioner berkaitan dengan proses pembelajaran mahasiswa tahun 2013, 2014 dan 2015 secara umum menyatakan bahwa mahasiswa mengalami kesulitan belajar/permasalahan penyusunan skripsi sebagai tugas individual dalam menyelesaikan studinya. Banyak faktor ditemukan terkait dengan kesulitan mereka dalam menyusun skripsi, salah satu diantaranya adalah penyusunan proposal penelitian. Proposal penelitian bermuara dari mata kuliah metodologi penelitian pendidikan (MPP).

Seperti halnya di Prodi Pendidikan Agama Hindu, permasalahan yang ditemukan dari hasil penelitian pendahuluan yaitu aktivitas dan prestasi belajar mahasiswa khususnya dalam mata kuliah Metode Penelitian masih rendah. Tuntutan dalam pembelajaran metode penelitian di Prodi Pendidikan Agama Hindu, salah satunya adalah diakhir perkuliahan mahasiswa diwajibkan memiliki sebuah proposal penelitian sebagai implementasi dari ilmu yang diperoleh dalam perkuliahan. Berdasarkan target tersebut banyak mahasiswa tidak bisa memenuhi target yang diinginkan, mereka masih lambat menginternalisasi ilmu yang 
diberikan oleh dosen. Aktivitas pembelajaran yang rendah berdampak pada lambatnya mahasiswa menyelesaikan tugas akhir Semester sehingga nilai kelulusannya pun terlambat/molor. Jika dalam batas waktu yang ditetapkan mahasiswa juga tidak bisa menyetorkan tugas akhirnya maka nilainya pun menjadi rendah (tidak lulus). Dari hasil analisis terhadap hasil pembelajaran sebelumya terutama dalam mata kuliah metode penelitian pendidikan ditemukan bahwa rendahnya prestasi belajar yang ditunjukkan dengan IP Semester. Hanya 10\% yang memperoleh hasil belajar dengan (IP 3,5-4,0) selebihnya IP mahasiswa < 3,4. Rendahnya prestasi belajar mahasiswa disebabkan tugas akhir (proposal penelitian) tidak bisa diselesaikan dengan baik dan tepat waktu. Proposal penelitian merupakan produk akhir yang memiliki bobot tinggi (4) dari lima aspek penilaian. Mengingat pengelolaan proses pembelajaran merupakan stimulus yang harus diciptakan oleh pengajar/dosen, maka permasalahan seperti di atas harus dilihat dari sudut pengajar/dosen. Ada beberapa faktor yang dapat mengakibatkan rendahnya aktivitas belajar mahasiswa antara lain: 1) dosen belum memahami karakteristik metode/model pembelajaran yang inovatif; 2) kurangnya informasi berkaitan dengan metode mana yang efektif (sudah teruji) dan metode mana yang tidak efektif (belum teruji); 3) adanya kebiasaan buruk pengajar yaitu asal menggunakan metode dan kurang mempertimbangkan efektivitasnya; 4) dalam mengelola proses Pembelajaran pengajar cenderung menggunakan pendekatan"teacher centered" dengan metode ceramah. Kondisi demikian tentu membuat proses pembelajaran hanya dikuasai pengajar. Hasil wawancara dengan pengampu mata kuliah membenarkan bahwa sebagian besar mahasiswa belum mampu menuangkan pikiran/ide/gagasannya menjadi sebuah proposal penelitian. Mereka cenderung meniru yang sudah ada sehingga orisinalitas ide/gagasannya masih rendah. Hal ini disebabkan karena proses pembelajaran yang digunakan dosen kurang memberi kesempatan kepada mahasiswa untuk melatih aktivitas mental dan fisik. Metode pembelajaran yang konvensional tentu tidak memberi kontribusi yang cukup kepada mahasiswa untuk mengeksflorasi pengetahuannya. Banyak metode yang bisa digunakan dosen, namun cara memilih metode yang tepat harus menjadi prioritas utama bagi dosen dalam pembelajaran. Metode yang baik disamping penggunaannya yang tepat keterandalannya juga penting harus dipertimbangkan. 
Metode dinyatakan andal/valid jika telah diuji secara signifikan melalui penelitian eksperimen.

Menyimak permasalahan yang dihadapi mahasiswa tersebut di atas perlu diupayakan agar dosen mempunyai referensi yang cukup dan teruji efektivitas dan efesiensinya dari suatu metode tertentu. Untuk memenuhi maksud tersebut penelitian eksperimen memegang peran penting, karena hasil yang diperoleh dapat memberikan referensi yang pasti tentang efektivitas suatu metode pembelajaran. Penelitian eksperimen adalah suatu penelitian yang salah satunya bertujuan untuk menguji suatu gejala dalam kaitan dengan judul ini adalah metode pembelajaran. Dunia pendidikan banyak mengenal berbagai macam metode dalam pembelajaran namun metode yang digagas melalui model pembelajaran yang bersumber dari budaya lokal atau sastra Hindu masih sangat terbatas, padahal ajaran Agama Hindu sangat kaya akan gagasan-gagasan metode pembelajaran. Seperti halnya: konsep ajaran Tri Pramana, konsep ajaran Catur guru, konsep ajaran Tri Kaya Parisudha dan banyak lagi yang lainnya. Dalam penelitian ini digunakan konsep ajaran Tri Kaya Parisudha karena konsep ajaran ini memuat tiga komponen yaitu: komponen manacika, wacika dan kayika. Konsep ini memberi inspirasi seorang dosen/guru dalam menyampaikan materi pembelajarannya memasukkan komponen: berpikir (diinspirasi dari konsep manacika), berbicara (diinspirasi dari konsep wacika), melakukan/mengerjakan (diinspirasi dari kayika). Jadi pembelajaran Tri Kaya Parisudha berarti pembelajaran dikemas agar anak aktif berpikir, berbicara dan mengerjakan/melakukan sesuatu sesuai dengan materi ajar. Konsep berpikir, berbicara dan mengerjakan/melakukan merupakan hakekat dasar dari suatu pembelajaran inovatif. Namun sampai saat ini belum ada penelitian yang khusus menguji apakah konsep ajaran Tri Kaya Parisudha efektif atau tidak, dipandang perlu dilakukan pengujian melalui penelitian eksperimen yang nantinya diperoleh metode pembelajaran baru yang bersumber pada satra agama Hindu. Beberapa kajian teori dan pustaka yang digunakan untuk memperkuat temuan hasil penelitian adalah: 


\section{Konsep Ajaran Tri Kaya Parisudha}

Penerapan pembelajaran dengan menggunakan konsep ajaran Tri Kaya Parisudha dilihat dari konsep dasar yang terdiri dari tiga hal yaitu: manahcika, wacika dan kayika. Hal ini bisa di tinjau dari pengertian ajarannya yang memanfaatkan tiga komponen dasar manusia yakni berpikir (think), berkata (talk) dan berbuat $(a c t)$. Ketiga elemen ini sangat potensial untuk meningkatkan kualitas proses dan prestasi belajar mahasiswa jika dosen mampu memanfaatkan secara baik dan benar. Penerapan pembelajaran berkonsep ajaran Tri Kaya Parisudha ini bertujuan agar mahasiswa mampu berpikir kritis, terampil dan berani berbicara, serta tekun, ulet untuk mencari/menemukan, mengerjakan sesuatu dalam memperoleh pengetahuan.

a) Pendekatan proses pembelajaran manacika

Manacika diartikan berpikir yang baik dan benar sesuai ajaran dharma. Dalam proses pembelajaranya konsep ini diterapkan dengan berbagai model/pendekatan atau metode belajar yang menekankan aktivitas berpikir aktif, kreatif. Menumbuhkan aktivitas berpikir dosen/guru dapat menggunakan metode Tanya jawab, tugas, problem solving, membaca teks dan lain-lain. Memberikan penugasan kepada mahasiswa untuk dibahas atau didiskusikan kemudian dipresentasikan di depan kelas.

b) Pendekatan proses pembelajaran wacika

Sama halnya seperti penerapan pembelajaran berkonsep manacika, dalam ajaran agama Hindu Wacika diartikan berkata yang baik dan benar sesuai norma yang berlaku. Konsep ini menekankan aktivitas dan keterampilan berbicara yang merupakan keterampilan dasar untuk memperoleh dan memperkaya ilmu pengetahuan. Dalam pembelajaran dapat dilakukan dimana mahasiswa diminta untuk mempresentasikan hasil karya, temuan penelitian/observasi, simpulan hasil diskusi dan sejeninya. Cara penyampaian pendapat atau memberikan sanggahan terhadap pendapat yang lain perlu mencerminkan adanya pembelajaran yang berkonsep ajaran wacika.

c) Pendekatan proses pembelajaran kayika

Pada pembelajaran berkonsep kayika ini peserta didik dituntun agar mampu melakukan/mengerjakan permasalahan yang diberikan oleh dosen/guru. 
Pembelajaran dapat dikemas agar proses pembelajaran dapat mengaktifkan gerak/fisik disamping aktivitas mental. Seperti meragakan, mendemontrasikan, mempraktekkan dan sejenisnya. Pembelajaran yang dilakukan dengan mengaktifkan gerak/fisik dapat lebih menyenangkan, lebih mudah dipahami dan tersimpan dalam memori dalam waktu relatif lama. Penerapan model pembelajaran Tri Kaya Parisudha, ketiga aspek yaitu: kayika, wacika dan manacika dapat dibolak balik posisinya sesuai kebutuhan. Seperti: kayika, wacika, manacika (perilaku/melakukan, bicara, berpikir) pembelajaran dirancang diawali dengan inquiry learning dilanjutkan forum group discusstion dan terakhir problem solving. Bisa juga dengan komposisi: manacika, wacika dan kayika (berpikir, berbicara dan berbuat/perilaku). Seni dalam memanajemen pembelajaran sangat dibutuhkan oleh seorang guru/pengajar. Di bawah ini disajikan salah satu model sintax pembelajaran Konsep Tri Kaya Parisudha.

Tabel. 01: Sintaks Pembelajaran Tri Kaya Parisudha

\begin{tabular}{|c|c|}
\hline $\begin{array}{c}\text { Konsep Ajaran Tri Kaya } \\
\text { parisudha }\end{array}$ & Sintaks Pembelajaran \\
\hline $\begin{array}{l}\text { Kayika, Act (Kegiatan/aktivitas) } \\
\text { Pembelajaran yang berorientasi } \\
\text { untuk menumbuh kembangkan } \\
\text { aktivitas belajar mahasiswa. } \\
\text { Metode pembelajarannya adalah: } \\
\text { Observasi, Inquiry Learning. }\end{array}$ & $\begin{array}{l}\text { Dalam upaya guru menumbuh kembangkan } \\
\text { perilaku/aktivitas belajar dapat dilakukan sebagai berikut. } \\
\text { 1. Memberi tugas/instruksi kepada mahasiswa } \\
\text { melakukan pengamatan, mencatat secara sistematis } \\
\text { tentang objek tertentu baik secara individual atau } \\
\text { berkelompok. } \\
\text { 2. Kegiatan ini bisa dilakukan di dalam Semester yang } \\
\text { sudah dirancang oleh guru sebelum mengajar. Bisa } \\
\text { juga dilakukan di luar kelas dalam bentuk tugas rumah } \\
\text { (PR), di perpustakaan atau pun di laboratorium (ICT). } \\
\text { 3. Guru memberikan langkah-langkah yang jelas agar } \\
\text { mahasiswa dapat memahami dan melaksanakan sesuai } \\
\text { dengan tujuan yang diinginkan. Hal ini diperlukan agar } \\
\text { perilaku belajar mahasiswa terarah sesuai tujuan. }\end{array}$ \\
\hline $\begin{array}{l}\text { Manacika, Think (Berpikir) } \\
\text { Pembelajaran yang menekankan } \\
\text { proses berpikir. Arah } \\
\text { pembelajaran mahasiswa mampu } \\
\text { menggunakan teknik berpikir } \\
\text { kreatif, logis dan benar. Metode } \\
\text { pembelajarannya Problem } \\
\text { Solving. }\end{array}$ & $\begin{array}{l}\text { Kegiatan pembelajaran meliputi: } \\
\text { 1. Guru memberikan permasalahan atau serangkaian } \\
\text { pertanyaan kepada mahasiswa terkait dengan materi } \\
\text { yang diamati. } \\
\text { 2. Pemecahan masalah dilakukan secara individual atau } \\
\text { kelompok. Peran guru adalah membimbing mahasiswa } \\
\text { dalam pemecahan masalah. } \\
\text { 3. Guru menyuruh mahasiswa untuk melakukan } \\
\text { eksplorasi dan elaborasi dengan sumber atau materi } \\
\text { lain. }\end{array}$ \\
\hline $\begin{array}{l}\text { Wacika, Talk (Berbicara) } \\
\text { Pembelajaran yang bertujuan } \\
\text { untuk melatih keberanian, } \\
\text { keterampilan, kemampuan } \\
\text { berbicara. Metode } \\
\text { Pembelajarannya adalah Forum }\end{array}$ & $\begin{array}{l}\text { Guru mendisain pembelajaran yang dapat } \\
\text { melatih/mengaktifkan kompetensi dalam berbicara. } \\
\text { Kegiatan ini satu rangkaian dengan kegiatan kayika di atas. } \\
\text { Oleh karena itu kegiatan pembelajaran guru adalah sebagai } \\
\text { berikut. }\end{array}$ \\
\hline
\end{tabular}




\begin{tabular}{|c|c|}
\hline $\begin{array}{l}\text { Group Discussion }(F G D) \text { atau } \\
\text { Forum Class Discussion }(F C D)\end{array}$ & $\begin{array}{l}\text { 1. Tugas yang telah dikerjakan oleh mahasiswa seperti } \\
\text { tersebut di atas (kayika) selanjutnya didiskusikan di } \\
\text { dalam kelas. Bisa dilakukan melalui kelompok Forum } \\
\text { Group Discussion (FGD) atau Forum Class Discussion } \\
\text { (FCD). } \\
\text { 2. Guru memberi kesempatan kepada mahasiswa secara } \\
\text { individual atau pun kelompok untuk } \\
\text { mempresentasikan materi yang diperoleh dari } \\
\text { tugas/pekerjaan rumah yang mereka kerjakan. } \\
\text { 3. Dapat memanfaatkan media Power Point, dimana guru } \\
\text { meminta mahasiswa menulis poin penting (pointers } \\
\text { content) dari temuan observasinya kemudian } \\
\text { dijelaskan di depan kelas. }\end{array}$ \\
\hline
\end{tabular}

Prestasi Belajar, prestasi belajar adalah hasil maksimal yang diperoleh seseorang setelah mengalami proses belajar di sekolah yang dinyatakan dalam bentuk angka atau bilangan (kognitif), dan diperoleh melalui instrumen tes hasil belajar.

Metode Pembelajaran Konvensional, metode pembelajaran konvensional adalah metode pembelajaran tradisional atau disebut juga dengan metode ceramah. Pembelajaran dilakukan di dalam kelas dimana dosen/guru hanya berfungsi sebagai penceramah, semua aktivitasnya berorientasi pada pemberian informasi saja yang wajib untuk diingat atau dihafal oleh mahasiswa.

Disamping beberapa kajian teori juga ada beberapa temuan hasil penelitian terdahulu antara lain: Ayu Eka Damayanti (2014) menyatakan bahwa pola pengajaran pendidikan Tri Kaya Parisudha dapat meningkatkan etika dan merubah prilaku mahasiswa dari perbuatan yang tidak baik menjadi baik mahasiswa di SDN Purwosari. Selanjutnya Sinarwati (2012) menyatakan bahwa menunjukkan bahwa penerapan model pembelajaran Kooperatif dengan strategi TTAR berda-sarkan Tri Kaya Parisudha dapat meningkatkan soft skills mahasiswa, tetapi masih dalam kategori cukup. Mahasiswa memberikan respon positif terhadap model pembelajaran yang diterapkan.

\section{Kerangka Berpikir}

Berdasarkan beberapa teori dan kajian hasil penelitian yang relevan yang telah diuraikan di atas yang mendukung variabel penelitian ini, maka kerangka pikir dapat digambarkan sebagai berikut. 


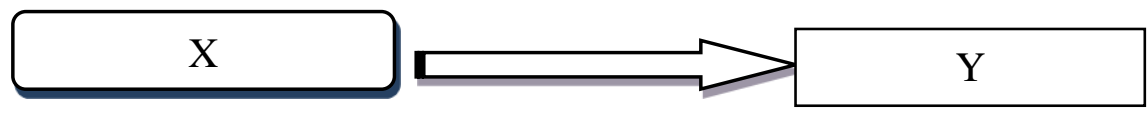

(Gambar: 02 Kerangka Berpikir)

Keterangan :

$\mathbf{X}=$ Model pembelajaran Tri Kaya Parisudha

$\mathbf{Y}=$ Prestasi Belajar

Dalam proses interaksi belajar mengajar dosen/guru adalah orang yang memberikan pelajaran dan mahasiswa adalah orang yang menerima pelajaran. Dalam mentransfer pengetahuan kepada mahasiswa diperlukan pengetahuan, kecakapan dan keterampilan sebagai dosen/guru. Tanpa itu semua tidak akan mungkin proses interaksi belajar mengajar dapat berjalan secara kondusif. Di sinilah kompetensi dalam arti kemampuan mutlak diperlukan dosen/guru dalam melaksanakan tugasnya sebagai pendidik. Salah satu kompetensi dosen/guru adalah kemampuan untuk menggunakan metode dalam pembelajaran, kompetensi dalam menggunakan pendekatan pembelajaran ini merupakan kemampuan mutlak yang dimiliki oleh dosen/guru untuk melaksanakan tugasnya sebagai pendidik dapat terlaksana dengan baik.

Dunia pendidikan banyak mengenal berbagai macam metode dalam pembelajaran namun metode yang digagas melalui konsep ajaran Agama Hindu masih sangat terbatas, padahal ajaran Agama Hindu sangat kaya akan gagasangagasan metode pembelajaran. Seperti halnya: konsep ajaran Tri Kaya Parisudha, konsep ajaran ini memuat tiga komponen yaitu: komponen manacika, wacika dan kayika. Konsep ini memberi inspirasi seorang dosen/guru dalam menyampaikan materi pembelajarannya yaitu memasukkan komponen: berpikir (diinspirasi dari konsep manacika), berbicara (diinspirasi dari konsep wacika), melakukan/mengerjakan (diinspirasi dari kayika). Jadi pembelajaran konsep ajaran Tri Kaya Parisudha berarti pembelajaran dikemas agar anak aktif berpikir, berbicara dan mengerjakan/melakukan sesuatu sesuai dengan materi ajar. Konsep berpikir, berbicara dan mengerjakan/melakukan, merupakan hakekat dasar dari suatu pembelajaran inovatif. Aspek perilaku (psikomotor) seperti diharapkan dalam pemenuhan kompetensi inti ke-4 (KI 4) kurikulum 2013 meliputi berbagai indikator yaitu: mengolah, menalar, menyaji, dan mencipta dalam ranah kongkret dan ranah 
abstrak terkait dengan pengembangan dari yang dipelajarinya di sekolah secara mandiri serta bertindak secara efektif dan kreatif, dan mampu menggunakan metode sesuai kaidah keilmuan. Perilaku belajar yang diinginkan muncul sebagai akibat dari stimulus dari tujuan dan materi pelajaran yang digunakan oleh dosen/guru. Stimulus yang diberikan oleh pengajar memunculkan respon si pelajar. Dalam penelitian ini stimulus yang digunakan adalah konsep ajaran Tri Kaya Parisudha dan respon mahasiswa berbentuk prestasi belajar. Semakin baik konsep ajaran Tri Kaya Parisudha diterapkan dalam pembelajaran diduga semakin baik pula prestasi belajar mata kuliah metodologi penelitian mahasiswa.

\section{METODE PENELITIAN}

Penelitian ini dirancang dengan penelitian eksperimen (experimental research) dengan model desain "Posttest only control group design. Desain penelitian digambar sebagai berikut.

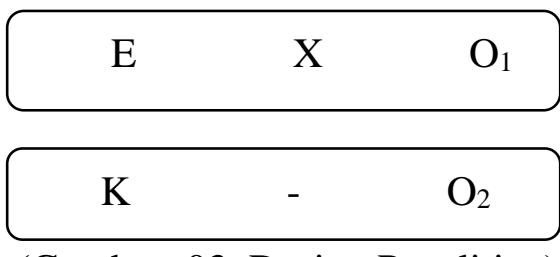

(Gambar: 03. Design Penelitian)

Keterangan:

$\mathrm{E} \quad=$ Kelas Exsperimen (Kelas yang diberikan treatment)

$\mathrm{K}=$ Kelas kontrol (Kelas yang tidak diberikan treatment)

$\mathrm{X} \quad=$ Treatment (Konsep ajaran Tri Kaya Parisudha)

$\mathrm{O}_{1}$ dan $\mathrm{O}_{2}=($ Post-test $)$

Oleh karena prodi ini terdiri dua kelas (kelas A dan B) maka semua mahasiswa diteliti sebagai subyek penelitian dengan jumlah 54 orang. Untuk menentukan kelompok/kelas eksperimen dan kontrol ditentukan dengan teknik undian. Ada pun anggota sampel dari hasil undian sebagai berikut. 
Tabel 02: Jumlah Anggota Sampel Mahasiswa Semester V Prodi Pendidikan Agama Hindu Tahun Akademik 2015/2016.

\begin{tabular}{|l|l|l|l|}
\hline No & \multicolumn{1}{|c|}{ Jenis Kelamin } & Jumlah Mahasiswa & Keterangan \\
\hline 1 & Kelas Eksperimen & 28 Orang & - \\
\hline 2 & Kelas Kontrol & 26 Orang & - \\
\hline \multicolumn{2}{|c|}{ Total } & 54 Orang & - \\
\hline
\end{tabular}

Ada pun variabel dalam penelitian ini adalah: konsep ajaran Tri Kaya Parisudha sebagai variable bebas (X) dan prestasi belajar mata kuliah metodologi penelitian sebagai variabel terikat (Y). Metode pengumpulan data dalam penelitian ini adalah: tes sebagai metode utama, dan observasi, wawancara serta pencatatan dokumen sebagai metode pelengkap. Metode analisis data digunakan t-test rumus polled varians seperti di bawah ini.

$$
t=\frac{\bar{X}_{1}-\bar{X}_{2}}{\sqrt{\frac{\left(n_{1}-1\right) s_{1}^{2}+\left(n_{2}-1\right) s_{2}^{2}}{n_{1}+n_{2}-2}\left(\frac{1}{n_{1}}+\frac{1}{n_{2}}\right)}}
$$

(Sugiono, 2003)

Analisis data dilengkapi dengan uji normalitas data dan uji homogenitas varian menggunakan fasilitas SPSS 16.0 For Windows.

\section{HASIL PENELITIAN DAN PEMBAHASAN}

\section{A. Hasil Penelitian}

\section{Analisis Data Kelas Eksperimen}

Data yang diperoleh didistribusi dalam tabel data sebagai berikut.

Tabel 03. Tabel Distribusi Prestasi Belajar Kelas Eksperimen (SM V B)

\begin{tabular}{|c|c|c|c|}
\hline $\begin{array}{c}\text { Skor } \\
(\mathbf{X 1})\end{array}$ & $\begin{array}{c}\text { Frekuensi } \\
\text { Observasi (f) }\end{array}$ & $\begin{array}{c}\text { Frekuensi } \\
\text { Relatif } \\
\left(\mathbf{f}_{\mathbf{r}}\right)\end{array}$ & $\begin{array}{c}\text { Frekuensi Relatif } \\
\text { Komulatif } \\
(\mathbf{f k r})\end{array}$ \\
\hline $\mathbf{1}$ & $\mathbf{2}$ & $\mathbf{3}$ & $\mathbf{4}$ \\
\hline 94 & 2 & 7,14 & 100,00 \\
\hline 90 & 5 & 17,86 & 92,85 \\
\hline 86 & 1 & 3,57 & 75,00 \\
\hline 85 & 5 & 17,86 & 71,43 \\
\hline 84 & 6 & 21,43 & 53,57 \\
\hline 80 & 7 & 25,00 & 32,14 \\
\hline 75 & 2 & 7,14 & 7,14 \\
\hline Jumlah & $\mathbf{2 8}$ & - & - \\
\hline
\end{tabular}


Data di atas selanjutnya dideskripsi menggunakan analisis statistik dengan fasilitas SPSS 16.0 for Windows dengan langkah-langkah sebagai berikut. Pilih tab variable view ketik $\mathrm{X}_{1}$ pada baris 1 kolom 1, pilih tab data view, masukkan data pada kolom $\mathrm{X}_{1}$, selanjutnya pilih menu analyze, descriptive statistics, descriptive, selanjutnya pilih $\mathrm{X}_{1}$ masukkan ke dalam kotak variable, klik tombol option, pilih mean, sum, std. deviation, variance, range, minimum, maximum, klik continue lalu $o k$. Hasil analisis disajikan pada tabel berikut ini.

Tabel 04. Deskripsi Data Distribusi Prestasi Belajar Kelas Eksperimen

\begin{tabular}{|c|l|c|}
\hline No & \multicolumn{1}{|c|}{ Uraian } & Jumlah \\
\hline $\mathbf{1}$ & \multicolumn{1}{|c|}{$\mathbf{2}$} & $\mathbf{3}$ \\
\hline 1. & Jumlah Sampel (N) & 28 \\
\hline 2. & Rata-rata (Mean) & 84,39 \\
\hline 3. & Simpangan Baku (Std. Deviation) & 4,94 \\
\hline 4. & Rentangan Skor (Range) & 19,00 \\
\hline 5. & Variansi (Variance) & 24,40 \\
\hline 6. & Skor Minimum & 75,00 \\
\hline 7. & Skor Maksimum & 94,00 \\
\hline 8. & Jumlah Skor $($ Sum $)$ & 2363,00 \\
\hline
\end{tabular}

Berdasarkan pada tabel di atas diketahui skor terendah yang diperoleh mahasiswa Kelas eksperimen (SM V B) adalah 75,00 dan skor tertinggi 94,00, simpangan baku (std. deviation) 4,94 rentangan skor (range) 19,00, variansi (variance) 24,40, dan rata-rata (mean) 84,39. Data di atas dapat disajikan dalam grafik histogram berikut.

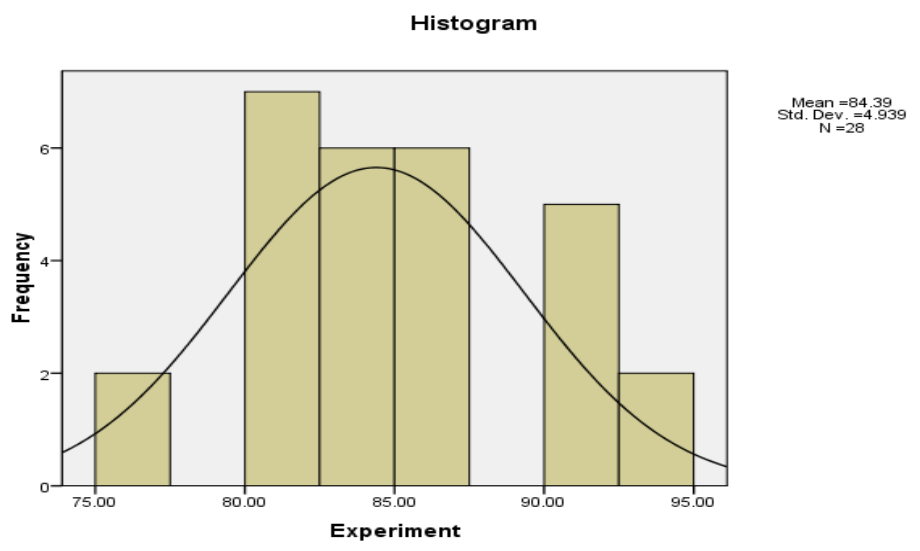

Gambar 04. Histogram Prestasi Belajar Kelas Eksperimen 
Dari histogram di atas dapat dilihat posisi skor mahasiswa, ke arah kanan kurva adalah daerah yang menunjukkan skor tinggi. Semakin ke kanan semakin tinggi jumlah skornya. Di daerah kurva normal ditempati oleh skor antara 80 sampai dengan 86 dengan jumlah mahasiswa sebanyak 19 sedangkan dibagian ujung kanan ditempati skor 90 dan 94 dengan jumlah mahasiswa sebanyak 7 orang. Maka dapat disimpulkan bahwa kelas eksperimen posisi skor dalam kurva normal kebanyakan menempati posisi normal ke atas (kurva cederung condong ke kanan/skor tinggi).

\section{Analisis Data Kelas Kontrol}

Data yang diperoleh didistribusi dalam tabel data sebagai berikut.

Tabel 05. Tabel Distribusi Prestasi Belajar Kelas Kontrol

\begin{tabular}{|c|c|c|c|}
\hline $\begin{array}{l}\text { Skor } \\
\left(\mathbf{X}_{2}\right)\end{array}$ & $\begin{array}{c}\text { Frekuensi } \\
\text { Observasi (fo) }\end{array}$ & $\begin{array}{l}\text { Frekuensi } \\
\text { Relatif } \\
\left(\mathbf{f}_{\mathbf{r}}\right)\end{array}$ & $\begin{array}{c}\text { Frekuensi Relatif } \\
\text { Komulatif } \\
\text { (fkr) }\end{array}$ \\
\hline 1 & 2 & 3 & 4 \\
\hline 85 & 1 & 3,85 & 100,00 \\
\hline 83 & 1 & 3,85 & 96,15 \\
\hline 82 & 1 & 3,85 & 92,31 \\
\hline 80 & 3 & 11,54 & 88,46 \\
\hline 78 & 1 & 3,85 & 76,92 \\
\hline 76 & 1 & 3,85 & 73,08 \\
\hline 75 & 3 & 11,54 & 69,23 \\
\hline 74 & 2 & 7,69 & 57,69 \\
\hline 70 & 3 & 11,54 & 50,00 \\
\hline 68 & 3 & 11,54 & 38,46 \\
\hline 65 & 7 & 26,92 & 26,92 \\
\hline Jumlah & 26 & - & - \\
\hline
\end{tabular}

Data di atas selanjutnya dideskripsi menggunakan analisis statistik dengan fasilitas SPSS 16.0 for Windows dimana langkah-langkahnya adalah sebagai berikut. Pilih tab variable view ketik $\mathrm{X}_{2}$ pada baris 2 kolom 1, pilih tab data view, masukkan data pada kolom $\mathrm{X}_{2}$, selanjutnya pilih menu analyze, descriptive statistics, descriptive, selanjutnya pilih $\mathrm{X}_{2}$ masukkan ke dalam kotak variable, klik tombol option, pilih mean, sum, std. deviation, variance, range, minimum, maximum, klik continue lalu $O k$. Hasilnya disajikan pada tabel berikut ini. 
Tabel 06. Deskripsi Data Distribusi Prestasi Belajar Kelas Kontrol

\begin{tabular}{|c|l|c|}
\hline No & \multicolumn{1}{|c|}{ Uraian } & Jumlah \\
\hline $\mathbf{1}$ & \multicolumn{1}{|c|}{$\mathbf{2}$} & $\mathbf{3}$ \\
\hline 1. & Jumlah Sampel (N) & 26 \\
\hline 2. & Rata-rata (Mean) & 17.19 \\
\hline 3. & Simpangan Baku (Std. Deviation) & 7.90 \\
\hline 4. & Rentangan Skor (Range) & 20.00 \\
\hline 5. & Variansi (Variance) & 62.40 \\
\hline 6. & Skor Minimum & 65.00 \\
\hline 7. & Skor Maksimum & 85.00 \\
\hline 8. & Jumlah Skor $($ Sum $)$ & 1929.00 \\
\hline
\end{tabular}

Berdasarkan pada tabel di atas diketahui skor terendah yang diperoleh mahasiswa Semester V A adalah 65,00 dan skor tertinggi 85,00, simpangan baku (std. deviation) 7,90, rentang skor (range) 20,00, variansi (variance) 62,40, dan angka rata-rata (mean) 74,19. Data di atas dapat disajikan dalam grafik histogram berikut.

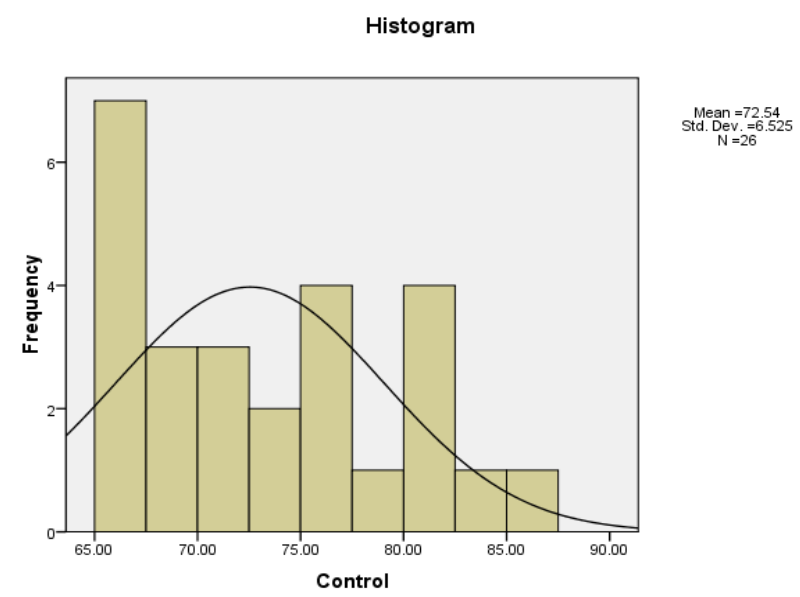

\section{Gambar 05. Histogram Prestasi Belajar Kelas Kontrol}

Dari histogram di atas dapat dilihat posisi skor mahasiswa, ke arah kiri kurva adalah daerah yang menunjukkan skor rendah. Semakin ke kiri semakin rendah jumlah skornya. Skor mahasiswa dominan menempati daerah kiri kurva dan di daerah kanan kurva hanya terdapat tiga skor yaitu 82,83, dan 85 masing-masing 1 orang. Maka dapat disimpulkan bahwa skor kelas kontrol membentuk kurva condong ke kiri /skor rendah). 


\section{Uji Hipotesis Penelitian}

Berdasarkan analisis di atas dengan taraf signifikansi 5\% (0,05) dengan $d k$ = 52 diperoleh bahwa ada perbedaan pengaruh model konsep ajaran Tri Kaya Parisudha terhadap prestasi belajar Mahasiswa STKIP Agama Hindu Singaraja, yang ditunjukkan dengan perbedaan rata-rata kelas antara kelas eksperimen dengan kelas kontrol. Rata-rata kelas eksperimen $(84,36)$ lebih besar dari rata-rata kelas kontrol $(72,44)$. Berdasarkan hasil tersebut disimpulkan bahwa ada pengaruh model pembelajaran Tri Kaya Parisudha terhadap prestasi belajar Mahasiswa STKIP Agama Hindu Singaraja.

\section{B. Pembahasan}

Berdasarkan hasil analisis di atas, didapatkan bahwa ada pengaruh model pembelajaran Tri Kaya Parisudha terhadap prestasi belajar Mahasiswa STKIP Agama Hindu Singaraja. Pengaruh model pembelajaran Tri Kaya Parisudha terhadap prestasi belajar Mahasiswa STKIP Agama Hindu Singaraja ditunjukkan dengan adanya perbedaan prestasi antara kelas eksperimen dengan kelas kontrol. Hal ini disebabkan karena pengaruh model konsep ajaran Tri Kaya Parisudha yang diterapkan pada kelas eksperimen tidak menimbulkan kebosanan pada mahasiswa, karena dengan metode ini proses pembelajaran dikemas dengan model kelompok dan diskusi sehingga proses pembelajaran menjadi sangat menarik. Dengan pembelajaran model konsep ajaran Tri Kaya Parisudha mampu membangkitkan motivasi mahasiswa dalam melaksanakan suatu pembelajaran karena menuntut mahasiswa untuk aktif mengkontruksi sendiri materi sehingga lebih mudah memahami dan melekat dalam pikirannya. Konsep ajaran Tri Kaya Parisudha memberi inspirasi pembelajaran yang inovatif melibatkan aktivitas fisik dan aktivitas mental seperti tertuang dalam konsep ajaran Tri Kaya Parisudha (berpikir, berkata dan berbuat/melakukan). Seni guru dalam mengelola pembelajaran membuat proses berpikir, berkata dan melakukan dapat berkembang sangat dinamis dan menyenangkan bagi peseta didik (mahasiswa). Dari hasil observasi terhadap proses pembelajaran, menunjukkan gairah belajar mahasiswa sangat baik demikian juga aktivitas fisik dimana mahasiswa mencari, berdiskusi sangat aktif. Hal ini disebabkan mahasiswa terlibat secara aktif dalam memecahkan permasalahan dalam proses pembelajaran itu sendiri. Mahasiswa dapat berinteraksi baik dengan 
guru maupun sesama temannya untuk mendiskusikan permasalahan yang dibahas dalam anggota kelompok yang sebelumnya telah terbentuk. Berdasarkan hasil wawancara yang dilakukan terhadap mahasiswa yang menjadi objek penelitian, diketahui bahwa sebagian besar mahasiswa merasa senang jika diajarkan dengan menggunakan model pembelajaran tersebut yaitu penerapan konsep ajaran Tri Kaya Parisudha. Beberapa alasan yang disampaikan oleh mahasiswa adalah karena dengan menggunakan pembelajaran konsep ajaran Tri Kaya Parisudha suasana pembelajaran menjadi sangat kondusif, aktif dan para mahasiswa menjadi lebih kreatif karena pembelajarannya dikemas dalam bentuk memberikan kesempatan pada mahasiswa untuk menemukan sendiri pengetahuan yang sebelumnya belum mereka ketahui, sehingga lebih menumbuhkan jiwa sportivitas mahasiswa untuk menggali informasi lebih dalam lagi. Hal ini dapat memacu mahasiswa untuk bekerjasama dan berbagi pengetahuan dari mahasiswa yang sudah menguasai materi kepada anggota kelompok yang kurang memahami materi, sehingga setiap anggota kelompok akan mampu menguasai materi dengan baik.

Temuan penelitian di atas sejalan dengan temuan Endra Suanthara (2015) menyatakan bahwa penerapan pembelajaran dengan menggunakan konsep ajaran Tri Kaya Parisudha sangat baik untuk melatih kemampuan pikir, kemampuan berbicara dan kemampuan untuk mengaplikasikan atau menerapkan pengetahuan yang diperolehnya. Hal ini bisa di tinjau dari pengertian ajarannya yang memanfaatkan tiga komponen dasar manusia yakni berpikir (think), berkata (talk) dan berbuat $(a c t)$. Ketiga elemen ini sangat potensial untuk meningkatkan kualitas proses dan prestasi belajar mahasiswa jika dosen mampu memanfaatkan secara baik dan benar. Penerapan pembelajaran berkonsep ajaran Tri Kaya Parisudha ini bertujuan agar mahasiswa mampu berpikir kritis, terampil dan berani berbicara, serta tekun, ulet untuk mencari/menemukan, mengerjakan sesuatu dalam memperoleh pengetahuan. Abu Ahmadi, Widodo Supriyono (2007) menjelaskan secara teori bila sesuatu kegiatan dapat memuaskan suatu kebutuhan, maka ada kecenderungan besar untuk mengulanginya. Sumber penguat belajar dapat secara ekstrinsik (nilai, pengakuan, penghargaan) dan dapat secara intrinsik (kegairahan untuk menyelidiki, mengartikan situasi). Disamping itu mahasiswa memerlukan/ dan harus menerima umpan balik secara langsung derajat sukses 
pelaksanaan tugas (nilai raport/nilai test). Penelitian Lasia, Budiada (2014) dengan judul Penerapan Managemen Kontrol Berbasis Tri Kaya Parisudha di Laboratorium Kimia Analitik, menyimpulkan bahwa penerapan managemen kontrol berbasis Tri Kaya Parisudha sangat efektif di Laboratorium Kimia Analitik. Sedangkan pendapat mahasiswa terhadap penerapan managemen kontrol berbasis Tri Kaya Parisudha menujukkan respon yang positif. Sedangkan penelitian Rai Marta Dewi, Murda, Tegeh (2014) menemukan terdapat perbedaan hasil belajar ranah afektif siswa kelas V antara kelompok siswa yang dibelajarkan dengan model VCT berlandaskan konsep Tri Kaya Parisudha dengan kelompok siswa yang dibelajarkan dengan model pengajaran langsung (direct instruction). Hal ini ditunjukkan oleh $\mathrm{t}$ hitung $>\mathrm{t}$-tabel, $\mathrm{t}$ hitung $=6,60$, dan $\mathrm{t}$-tabel $=1,67$ dan didukung oleh perbedaan skor rata-rata yang diperoleh siswa yang dibelajarkan menggunakan model VCT berlandaskan konsep Tri Kaya Parisudha, yaitu 121 yang berada pada kategori tinggi dan model pengajaran langsung (direct instruction), yaitu 109,12 yang berada pada kategori sedang.

Berdasarkan uraian di atas jelaslah bahwa pembelajaran dengan konsep ajaran Tri Kaya Parisudha berpengaruh terhadap prestasi belajar mahasiswa semester V STKIP Agama Hindu Singaraja. Hasil penelitian ini direkomendasikan bahwa model pembelajaran tersebut di atas telah teruji secara signifikan dan layak digunakan dalam pembelajaran.

\section{SIMPULAN}

Berdasarkan analisis di atas disimpulkan sebagai berikut. Deskripsi prestasi belajar pendidikan agama Hindu kelas eksperimen diperoleh rata-rata (mean) sebesar 84,36 sedangkan kelas kontrol diperoleh rata-rata (mean) sebesar 72,44 . Dari analisis uji hipotesis ditemukan dimana $t_{h}(1,78)>$ dari $t_{t}(1,67)$ dengan taraf signifikansi $5 \%$ dan $d k 52$ diperoleh bahwa ada pengaruh pembelajaran Tri Kaya Parisudha terhadap prestasi belajar dalam mata kuliah MPP Mahasiswa Semester V STKIP Agama Hindu Singaraja. 


\section{DAFTAR PUSTAKA}

Anita, Sri W. 2001. Metode Belajar Mengajar. Bandung: Alfabeta

Arikunto, Suharsini. 2006. Dasar-Dasar Evaluasi Pendidikan. Jakarta: Bumi Aksara.

2006. Prosedur Penelitian, Suatu Pendekatan Praktek. Jakarta: Rineka Cipta

Adisusilo. 2012. Pembelajaran Nilai Karakter. Jakarta: PT Raja Grafindo Persada.

Djamarah dan Zain Aswan. 2002. Strategi Belajar Mengajar. Cetakan ke-II. Jakarta: Rineka Cipta

Elmubarok, Zaim. 2009. Membumikan Pendidikan Nilai. Bandung: Alfabeta.

Marta Dewi, dkk. 2014. Pengaruh Model VCT Berlandaskan Konsep Tri Kaya Parisudha Terhadap Hasil Belajar Ranah Afektif Siswa Kelas V di SD Gugus III Kecamatan Seririt Kabupaten Buleleng. Singaraja: FIP Universitas Pendidikan Ganesha.

Pendidikan Nasional. 2006. Kurikulum Tingkat Satuan Pendidikan (KTSP) Sekolah Dasar dan Madrasah Ibtidayah. Jakarta: https://sukes.wordpress.com/

Rohmat. 2004. Mengartikulasikan Pendidikan Nilai. Bandung: Alfabeta.

Saputra I Gede. 2009. Tri Kaya Parisudha. https://sukes.wordpress.com/tri-kayaparisudha/

Sinarwati Ni Kadek. t.t. Penerapan Pembelajaran Kooperatif Berdasarkan Tri Kaya Parisudha Untuk Meningkatkan Soft Skills Mahasiswa. Singaraja: file:///C:/Users/User/Downloads/4225-5354-1-SM.pdf

Sudharta, Tjok Rai. 2001. Upadesa tentang Ajaran Agama Hindu. Surabaya: Paramita. 